\title{
Efficacies and Impediments in Large Cardamom Farming in Ilam, Nepal
}

\author{
Thakur Bhattarai \\ Associate Professor, Tribhuvan University, Patan Multiple Campus, Nepal \\ Email: th.bhattarai@gmail.com
}

\begin{abstract}
Among all agricultural products produced in Nepal, large cardamom is the most expensive commercial crop with the highest export potential. The crop was initiated in Ilam. And, Ilam remained in the top four among large cardamom producing districts in Nepal up to 2014/15. Hence, the district deserves a pedagogic and appreciable place in its cultivation. The district was purposively selected for the analysis of its efficacy and blemishes. For this, primary data were collected during 2007 and 2014.The main efficacies of the crop were its high price, use of marginal land in cultivation, use of manpower mostly during off-season of other farming, need of less capital, and a common (familiar) crop. Suitable climate, rainfall, temperature range, export performance, tariff advantages, and availability of varieties were other plus points of the crop. The promises in its cultivation included prospects of quality improvement, growth in productivity, and easy approach to market. The challenges and weaknesses of the crop included diseases, lack of disease free saplings and seedlings, price fluctuations, drying of water sources for irrigation, and lack of government support in its cultivation and marketing. The crop was found popular in the study area due to its efficacies, which had outstripped its blemishes or flaws.
\end{abstract}

Key words: large cardamom, efficacy, impediments, employment

\section{BACKGROUND}

In common to almost all under developed countries in the world like Nepal, agriculture has been the main occupation of people. Large cardamom has been the topmost commercial crop identified among all exportable commodities of Nepal (International Trade Center [ITC], 2007a \& 2007b; Ministry of Commerce and Supplies, Nepal [MOCS], 2010). This eco-friendly, labour-intensive, and the third-most expensive spice crop in the world was initiated in Nepal in Ilam district and gradually spread in other parts of the country (Sharma, 1999; Lungeli, 2001; Poudal, 2004).

Large cardamom was initiated in Ilam during 1850s by Lepcha Kajis, importing it from Sikkim (Sharma, 1999; Bhattaray, 2001). The contribution of Ilam district in the production and export of large cardamom was more than 21 percent up to 2008/09. 
Though there was reduction in the production in the district after 2008, the district contributed more than 18 percent in the total production and export during 2001/02 to 2014/15 (Ministry of Agriculture and Cooperative [MOAC], 2002; MOAD, 2015a). These facts and figures show that Ilam deserved a unique and distinct place in the production and export of large cardamom.

It is opined that the success of the cultivation of large cardamom in the district has stimulated the farmers in the area for innovative approach in farming (District Development Committee [DDC], Ilam, 2060 BS). Apart from the production of large cardamom, people from the district were involved in the production of tea, milk, potato, ginger and other crops. This had contributed in the commercialization of agriculture, and consequently on the transformation of the economy. This shows that Ilam district could be taken as a model for agriculture transformation. Hence, Ilam and large cardamom production were selected purposively for the study.

\section{REVIEW OF LITERATURE}

Agricultural crops produced in Nepal could be classified on the basis of the purpose of production broadly to subsistence crops and commercial crops. Among them, commercial crops are produced to earn income. Such crops can be further classified into products intended to sell at home, and products for export purpose. Large cardamom has been the main exportable commercial crop since 1960s, and has contributed 2.25 percent in the total export from Nepal during 1974/75 to 2014/15. The contribution was further extended to more than four percent during 2010s (MOAC, 2002; MOAD, 2015a).

The crop is mainly grown in the sub-Himalayan region of Nepal, India and Bhutan in such slope lands where the temperature ranged from $5^{\circ} \mathrm{C}$ to $30^{\circ} \mathrm{C}$, and annual rainfall ranged between 1,500 to $2,500 \mathrm{~mm}$. It is used widely as a spice in different food items and drinks, in preparation of different ayurbedic medicines, in pan, pan parag, gutka and other tobacco items, in different religious offerings, and as a mouth refresher. The crop is the most expensive spice crop in the world after saffron and vanilla (Cardamom Development Center [CDC], Ilam, 2014 field visit; DDC, Ilam, 2060 BS). According to Sharma, Sharma, Singh and Sharma (2000), the farming is more suitable in the slopes of hills and mountains where the soil is competitively soft and is formed by thin silty rocks, which are easily eroded. They have also mentioned that the traditional farming system would aggravate the extent of soil erosion, result in permanent deforestation, and would worsen the environmental destruction. In such areas, perennial and shade- 
loving crop like large cardamom would be the best alternative. It would not need frequent tillage, would prevent deforestation in such areas, and encourage people to plant trees. This would support biodiversity conservation. Barah (2010) and Gudade et al. (2014) have also similar conclusions.

Subedi (1982), Chhetri (2002) and Pradhan (2003) have stated the use of marginal land as the main benefit, and problems of marketing and price fluctuations as the main problems in large cardamom farming. Subedi (1982), Ghimire (1985), Zomer and Menke (1993), Mishra (1999) and Gautam (2002) have found large cardamom very helpful in conservation of biodiversity, environment and sustainability. They have also mentioned the problems of lack of proper knowledge of plantation and processing and attack of diseases as the main obstacles in its farming. Pant (2005) has pointed out the problem of absence of quality standardization as the main weakness in its trading, and highlighted on the cumbersome process of trade documentation, for its export. The problem of "black-hole effect" was in favour of India in its marketing (Chaulagai, 2013). Lepcha (2001) has indicated buyers' cartels, decreasing trend in the yield, aging of plants, traditional mode of drying, and rapid spread of diseases as the main problems. MOAD (2015b) has analyzed the strengths, weaknesses, opportunities and threats of large cardamom, and found it a promising crop in the Eastern Development Region of Nepal.

\section{Research Gap}

Among the works reviewed, some of the studies were carried out for the partial fulfillment of the requirement for Masters' degree. Most of them dealt with either a particular aspect, or were based on small size of samples, or were carried out many years back. Some were related to specific issue only. Among them, Ministry of Agriculture Development, Nepal (MOAD, 2015b) has analyzed different aspects of large cardamom farming. But this study was only a macro study that provided an overview of strengths, weaknesses, opportunities and threats (SWOT) in general. It was felt necessary to focus on the study in micro level in the area from where the crop was spread over other parts of the country.

\section{METHODOLOGY}

The district had 49 village development committees (VDCs) and one municipality during the field studies in 2007 and 2014. Out of them, 15 VDCs namely Barbotey, Chamaita, Fikkal, Jamuna, Jirmaley, Kanyam, Kolbung, Mai Pokhari, Mangalbarey, Naya Bazaar, Panchakanya, Samalbung, Shree Antu, Soyang and Sulubung were 
selected purposively on consultation with the personnel from district level agricultural offices. These were the area where large cardamom was commonly found. The VDCs were excluded where large cardamom farming was less common.

The study is based on the data collected by the researcher himself during 2007 and 2014 in the mentioned VDCs. Out of 3,009 large cardamom farmers who cultivated large cardamom in more than 0.05 hectare in the 15 village development committees (VDCs) sampled, 339 farm households were selected for both 2007 and 2014 field studies. Thus, the number of observation totaled to 678 households. Primary data was collected from the households that cultivated large cardamom through questionnaire, interviews, group discussions, expert opinions, and field observations. The sampling procedure was multi-stage stratified cum random sampling.

Scoring was done to evaluate different aspects of the crop and to come into conclusion. To find out the score for the analysis, the first preference was given two points, and the second preference was given one point. After calculation of the total score, it was expressed in percentage to make the analysis more apparent and lucid.

\section{FINDINGS OF THE STUDY}

Analysis of positive and negative elements related to any particular production, and its alternatives is necessary not only to identify the situation of any production, but also for necessary adjustments and improvement / development in its performance. Proper decision making is possible only after identifying such efficacies, together with its flaws. For it, various facets related to different aspects are needed. An attempt has been made here to analyze various positive and negative factors those boost, inhibit or hinder the large cardamom cultivation practice.

\section{Efficacies}

\section{a. Strengths}

Information was collected to find supporting conditions for large cardamom farming. For this, options were given and the informants were asked to give first and second preferences to the main and the second best option of the crop. These options included the options identified by ITC (2007a), MOCS (2010) and MOAD (2015a \& 2015b) as the strengths, and other strengths were also identified after discussions with agronomists and experts related to large cardamom farming. The finding of the field study is presented in Table 1. 
Table 1: Strengths of Large Cardamom Farming

\begin{tabular}{lcccccc}
\hline $\begin{array}{l}\text { What is better with it } \\
\text { than in other crops? }\end{array}$ & $\begin{array}{c}\text { First } \\
\text { preference }\end{array}$ & $\begin{array}{c}\text { Second } \\
\text { Preference }\end{array}$ & $\begin{array}{c}\text { Score } \\
(\%)\end{array}$ & $\begin{array}{c}\text { First } \\
\text { preference }\end{array}$ & $\begin{array}{c}\text { Second } \\
\text { Preference }\end{array}$ & Score (\%) \\
\hline $\begin{array}{l}\text { High price } \\
\text { commodity }\end{array}$ & 144 & 83 & 36.48 & 109 & 131 & 34.32 \\
$\begin{array}{l}\text { Use of marginal land } \\
\begin{array}{l}\text { Use of manpower } \\
\text { during off-season }\end{array}\end{array}$ & 120 & 38 & 27.34 & 198 & 94 & 48.18 \\
$\begin{array}{l}\text { Less capital } \\
\text { investment needed }\end{array}$ & 13 & 135 & 22.52 & 10 & 65 & 8.36 \\
$\begin{array}{l}\text { Familiar / common } \\
\text { crop }\end{array}$ & 10 & 12 & 3.15 & 2 & 23 & 5.80 \\
No response & 5 & 3 & 1.28 & 2 & 3 & 0.69 \\
\hline
\end{tabular}

Source: Field Surveys 2007, 2014.

Majority of the farmers in 2007 opined that

high price was the main advantage of the crop. Majority of the farm households (more than 36 percent) in 2014 viewed that the main strength of large cardamom farming was the use of marginal land. The respondents opined that gullies, north faced / shaded lands, river banks, sloped areas and barren lands were used for large cardamom. They would remain uncultivated if large cardamom was not cultivated. Thus, large cardamom farming enabled them to acquire something from such lands from which nothing could be gained otherwise. Thus, large cardamom farming provided an opportunity of rational use of idle land. It can be said that this had certainly provided opportunities to uplift their living standard.

In the view of nearly 23 percent of large cardamom farmers in 2007, it needed manpower mostly during off season of other crops. This was supported by more than eight percent of farmers during 2014 also. It showed that large cardamom farming was helpful to solve seasonal unemployment problem to some extent.

Approximately nine percent of the farmers in 2007 opined that large cardamom required less capital investment. Nearly six percent of the farmers agreed with it in 2014. So, it was a suitable crop in the area where capital was relatively scarce. Some of the farmers took it as one of the familiar crops. Thus, large cardamom was appreciated 
mostly for the use of marginal land, for its high price, for the need of manpower during off-seasons of other farming, and for the need of less capital.

Different aspects related to strength of large cardamom farming were discussed with experts in this field also, and information was taken from past studies also. These strengths include:

- Climate and location: The best elevation needed for large cardamom farming is 800-2,000 meters from sea level, which is available in the field area. So, the area was suitable for cardamom farming (Based on interaction with experts from District Agriculture Development Office [DADO], Ilam and CDC, Ilam, 2014 field visit).

- Rainfall: Annual precipitation that large cardamom needs should be in the range of 1,500 - 2,500 mm. There must be rainfall for about 70 days between the months of October and April. This criterion was also fulfilled in the study area.

- Temperature: The best site for large cardamom farming should have temperature between 5 degree Celsius and 25 degree Celsius, which was found in the study area (Based on interaction with experts from CDC, Ilam, 2014). So, large cardamom farming could be extended in the area.

- Land availability: The crop was grown in such areas which were either marginal for other cultivation purposes, or were waste lands. Though some of such lands were used in tea and other farming in recent years, some land could be managed further for large cardamom cultivation.

- Export performance: ITC (2007a) identified the export performance of large cardamom the highest among all exportable products from Nepal. Information provided by different government sources also show good export performance. Nearly 98 percent of the product was exported. Therefore, the crop could be a good source of earning foreign exchange. In the total export earnings from Nepal, large cardamom contributed more than four percent during 2009/10 to 2014/15 (MOCS, 2010).

- Tariff advantage: ITC (2007a) and MOCS (2010) have mentioned high tariff advantages of large cardamom. Some countries had provided zero tariff advantage also (MOAD, 2015c).

- Varieties: Different varieties of large cardamom were found in the study area, which were suitable to different altitude and topography. Recently, a new variety 
- Pakhe, which is locally known as Salakpure, was also introduced which had comparatively more resistance power to diseases, and could also be grown in more open, less shaded and low lands (below 800 meters) also.

- Storage and Market: Large cardamom was found with some strengths related to market. The crop could relatively be kept for a longer time than most of other crops - it could be stored for up to three years. This would enable the farmers to wait till they would get suitable price in the market. This spice crop was the crop with the highest price in the market at one hand, and, on the other, could easily be packed in sacks and stored for longer time in farmers' warehouse or be easily transported to the market. So the storage and marketing of the crop were easy.

- Environmental Impacts: Large cardamom plants need shade. They could not face strong wind and direct sunlight for a long time. For it, provision of trees was necessary. It would help in afforestation and preservation of forests. So the benefits of afforestation and biodiversity preservation were also possible. Furthermore, dairy farming could also be done side by side as large cardamom farms could be the sources of fodder. Similarly, large cardamom is a perennial crop which could give output up to 20 to 25 years once it was planted. So, there was no need of tillage time and again. The roots of large cardamom would grasp the soil, and help in maintaining soil cohesion. This could help in control of land erosion, which could be common in slope lands if they were used in other traditional crop farmings such as maize, millet, wheat and paddy.

Thus, much strength was found in large cardamom farming in both farmers' and experts' point of view (Based on interviews with farmers and interaction with experts from DADO, Ilam, CDC, Ilam and National Spice Crop Development Centre, Lalitpur, 2014 field visit). These strengths could be turned into opportunities, and make the crop more promising and rewarding.

\section{b. Opportunities}

Government surveys and reports (ITC, 2007a; MOCS, 2010 and MOAD, 2015b) have shown possibility of land extension, possibility of the growth in the productivity with change in farming practices, possibility of earning more income by quality improvement of the product, and possibility to gain more income by direct approach to the 'end-markets'. The farmers were asked to choose among them and select the best and second best alternatives. The summary of the surveys is shown in Table 2. 
Table 2: Opportunities of Large Cardamom Farming

\begin{tabular}{lcccccc}
\hline & \multicolumn{3}{c}{2007} & \multicolumn{3}{c}{2014} \\
\cline { 2 - 7 } & $\begin{array}{c}\text { First } \\
\text { preference }\end{array}$ & $\begin{array}{c}\text { Second } \\
\text { preference }\end{array}$ & $\begin{array}{c}\text { Score } \\
(\%)\end{array}$ & $\begin{array}{c}\text { First } \\
\text { preference }\end{array}$ & $\begin{array}{c}\text { Second } \\
\text { preference }\end{array}$ & $\begin{array}{c}\text { Score } \\
(\%)\end{array}$ \\
\hline Land extension & 224 & 39 & 47.89 & 4 & - & 0.79 \\
Quality improvement & 79 & 207 & 35.89 & 212 & 102 & 51.72 \\
$\begin{array}{l}\text { Approach to main } \\
\text { market }\end{array}$ & 31 & 64 & 12.39 & 37 & 121 & 19.17 \\
Productivity growth & 3 & 25 & 3.05 & 65 & 96 & 22.22 \\
Not stated & 2 & 4 & 0.79 & 21 & 20 & 6.10 \\
\hline
\end{tabular}

Source: Field Surveys 2007, 2014.

As shown in Table 2, possibility of land extension for large cardamom farming was the main opportunity in farmers' view in 2007, which was at the bottom in 2014. Possibility of earning more by quality improvement was suggested as the second preference in 2007, whereas it was the top-most priority in the 2014 survey.

There were also other opportunities in large cardamom farming. They included quality improvement and the opportunities due to fewer competitors. There was opportunity for improvement in the quality. Large cardamom was dried mostly in traditional kilns where raw capsules were dried using firewood. The dried capsules would be darkened with smoke, and would contain smoky odour. Modern and improved kilns were developed in Cardamom Development Center, Ilam. These kilns used drums from which heat would be transmitted to the capsules without smoke. The smokeless and brighter capsules could improve the quality.

The main producers of this crop include Nepal, India and Bhutan. The specific climatic condition, rainfall and temperature most suitable for this crop are found in almost all the hilly parts and lower part of the mountain region of Nepal, Bhutan and Sikkim, India (Gudade et al, 2014). Thus, the producers / competitors were less. Small cardamom, or sukumel, could be taken as a substitute of this crop, but the shape, size and other outlooks of this crop and the aroma differed a lot. So, it could be said that this crop had very limited competitors.

In experts' view, the other opportunities in large cardamom farming, together with the opportunities mentioned above, included possibility of improvement in environment 
by extension of large cardamom farming and the possibility of earning more from exports through removal of international trade obstacles.

\section{Impediments}

\section{a. Weaknesses}

Interviews, group discussions, observations and expert opinions were used to collect information about the impediments of the crop. The summary of the impediments of large cardamom farming, in view of the farm households, is provided in Table 3.

Table 3: Impediments of Large Cardamom Farming

\begin{tabular}{|c|c|c|c|c|c|c|}
\hline & \multicolumn{3}{|c|}{2007} & \multicolumn{3}{|c|}{2014} \\
\hline & $\begin{array}{c}\text { First } \\
\text { preference }\end{array}$ & $\begin{array}{c}\text { Second } \\
\text { preference }\end{array}$ & $\begin{array}{l}\text { Score } \\
(\%)\end{array}$ & $\begin{array}{c}\text { First } \\
\text { preference }\end{array}$ & $\begin{array}{c}\text { Second } \\
\text { preference }\end{array}$ & $\begin{array}{c}\text { Score } \\
(\%)\end{array}$ \\
\hline Diseases & 312 & 5 & 61.85 & 285 & 9 & 56.93 \\
\hline $\begin{array}{l}\text { Lack of disease- } \\
\text { free sapling }\end{array}$ & 16 & 118 & 14.75 & 33 & 135 & 19.76 \\
\hline $\begin{array}{l}\text { Marketing } \\
\text { problem }\end{array}$ & 1 & 103 & 10.32 & - & - & - \\
\hline $\begin{array}{l}\text { Lack of } \\
\text { government } \\
\text { support }\end{array}$ & 3 & 92 & 9.64 & 13 & 165 & 18.88 \\
\hline Lack of credit & - & 11 & 1.08 & - & 23 & 2.26 \\
\hline No response & 7 & 10 & 2.36 & 8 & 7 & 2.26 \\
\hline
\end{tabular}

Source: Field Surveys 2007, 2014.

The main impediment in large cardamom farming, during both field surveys, in farmers' view, was problem of diseases. And, the second emphasis was lack of diseasefree sapling in 2007, whereas it was lack of government support in large cardamom farming in 2014. Lack of government support was in technical help and in branding the product.

Lack of access to key distribution channels was also the weakness of large cardamom farming in businessmen's point of view. Problem of marketing, as indicated by nearly one-third of the farmers in 2007, was not mentioned in 2014 survey. It was due to rapid 
extension in transportation network during the time at one hand, and involvement of more traders on the other.

\section{b. Threats}

According to large cardamom farmers, the farming was under different threats. Among them, the main threats included diseases, price fluctuations, drying of water sources, and adulteration. The main threats, in farmers' view, are summarized in Table 4.

Table 4: Threats in Large Cardamom Farming

\begin{tabular}{|l|c|c|c|c|c|c|}
\hline & \multicolumn{4}{|c|}{2007} & \multicolumn{3}{c|}{2014} \\
\cline { 2 - 7 } & $\begin{array}{c}\text { First } \\
\text { preference }\end{array}$ & $\begin{array}{c}\text { Second } \\
\text { preference }\end{array}$ & $\begin{array}{c}\text { Score } \\
(\%)\end{array}$ & $\begin{array}{c}\text { First } \\
\text { preference }\end{array}$ & $\begin{array}{c}\text { Second } \\
\text { preference }\end{array}$ & $\begin{array}{c}\text { Score } \\
(\%)\end{array}$ \\
\hline Diseases & 316 & 19 & 64.01 & 325 & 9 & 64.80 \\
\hline Price fluctuation & 12 & 262 & 28.12 & 2 & 192 & 19.27 \\
\hline $\begin{array}{l}\text { Drying of water } \\
\text { sources }\end{array}$ & 10 & 51 & 6.98 & 9 & 97 & 11.31 \\
\hline Adulteration & - & - & - & - & 34 & 3.34 \\
\hline Not stated & 1 & 7 & 0.88 & 3 & 7 & 1.28 \\
\hline
\end{tabular}

Source: Field Surveys 2007, 2014.

Threat of diseases was the main emphasis of majority of farmers in both the field surveys. In addition to it, price fluctuation was the second emphasis during both the times. The other threats included drying of water sources and adulterations.

More than three years of waiting time for return, reluctant to the change in modes of production, and post harvesting operations, emergence of small cardamom (sukumel) as a substitute for large cardamom were other threats mentioned by businessmen and experts.

In the comparative analysis of the efficacies and blemishes, the former seem to overweight the later. The complexities in its production were found less. Need of capital, for this production purpose, was less not only in its traditional mode of farming, but also in innovative changes. Source of lands for this crop were marginal or otherwise waste lands so that the opportunity cost of land was also nominal. Other benefits 
included environmental benefits, minimal need of external capital, and availability of sufficient manpower for its farming.

\section{CONCLUSION}

The main strength of large cardamom was the use of marginal or otherwise waste lands in the 2007 field survey. It was found that the farmers gave due importance to the use of marginal land in 2014 field survey also. This shows that the crop has negligible opportunity cost of land. That is, the extension of large cardamom would not replace the lands for other uses. So, this could provide additional opportunity to uplift the economic status of the people without any adverse effects in other farmings. The suitability of climate and location, rainfall, temperature, export performance, tariff advantages, availability of varieties of crop suitable to different geo-climatic conditions were other selves of the crop.

The opportunities included possibility of getting higher prices through finishing and other quality improvement measures, possibility of productivity growth with transformation of traditional mode of production to modern one, easy approach to markets due to extension in transportation and communication in the study area.

It was observed by the researcher in the field surveys that the need of manpower in large cardamom farming was mostly during off-seasons of other crops. This was one of the noteworthy contributions of large cardamom farming.

But, some weaknesses were also indicated by the farmers, which included diseases, lack of disease free saplings and seedlings, lack of government support in disease control and in the provision of disease free seedlings and saplings, and credit. Lack of access to key distribution channels and branding were also found.

The main threats in large cardamom farming were diseases, high price fluctuations, and drying up of water sources. Mixing up of churumpho, an inferior and indigenous variant similar to large cardamom in the study area, was also found common. This problem of adulteration would create disbelief among consumers. The consequence would be creation of distrust in Nepalese product.

It can be concluded from these facts that large cardamom had been a boon for the farmers in Ilam district despite some weaknesses and threats. The crop could contribute better if efforts were made by the stakeholders in overcoming such hurdles. For this, need of strong technical and financial support of the government, basically in the 
control of diseases as well as provision of disease free seedlings and saplings, and in provision of modern kiln are desired.

\section{References}

Barah, B. C. (2010). Hill agriculture problems and prospects for mountain agriculture. Indian Journal of Agricultural Economics, 65, 584-601.

Bhattaray, S. K. (2001). Financial analysis of cardamom production: A case study of Fikkal and Kanyam VDCs of Ilam district (Unpublished master's thesis). Patan Multiple Campus, Nepal.

Chaulagai, M. K. (2013). Indo-Nepal trade relation: The phenomenon of black hole effect. Economic Review, NRB Working Series. NRB-WP-19, 1-14.

Chhetri, D. M. (2002). Large cardamom cultivation in Sikkim: A case study of PetchreakMartam and Hee - Kyangbari gram panchayat units of West District (Unpublished master's thesis). Tribhuvan University, Nepal.

District Development Committee, Ilam. (2060 BS). Ilamkochinary [Identity of Ilam]. Ilam, Nepal: Author.

Gautam, K. R. (2002). Options for Marginal Farm in Nepalese Mountain. Final Report submitted to International Centre for Integrated Mountain Development (ICIMOD).

Ghimire, M. P. (1985). Growing Alnus trees over cardamom plantation for fuel wood in Ilam District. Nepal: Community Forestry Development Project - Mimeo, HMG/ UNDP/FAO.

Gudade, B. A., Chhetri, P., Gupta, U., Bhattrai, N. K., Deca, T. N., \& Vijayan, A. K. (2014). The study on eco-friendly practices of large cardamom (amomum subulatum roxburgh) cultivation in Sikkim and Darjeeling region. Ecology, Environment and Conservation, 20(1), 119-123.

International Trade Centre. (2007a). Large cardamom from Nepal - Export performance and potential. Kathmandu, Nepal: Asia Trust Fund.

International Trade Centre. (2007b). Export Potential Assessment in Nepal, Project NEP/ A1/01A, Advisory Services on Export Development of Primary Sectors of Nepal. Kathmandu, Nepal: Author.

Lepcha, R. (2001). A Study on the large cardamom cultivation in Mangan district of Sikkim (Unpublished master's thesis). Tribhuvan University, Nepal.

Lungeli, L. B. (2001). Cultivation, problems and contribution of large cardamom: A case study of the Sulubung VDC, Ilam district (Unpublished master's thesis). Tribhuvan University, Nepal. 
Ministry of Agricultural Development, Nepal. (2015a). Statistical information on Nepalese agriculture 2014/2015. Kathmandu, Nepal: Author.

. (2015b). Trade flow analysis of large cardamom in eastern region. Kathmandu, Nepal: Author.

. (2015c). Agriculture development strategy 2015-2035(1). Kathmandu, Nepal: Author.

. (2002). Statistical information on Nepalese agriculture 2001/2002. Kathmandu, Nepal: Author.

Ministry of Commerce and Supplies, Nepal. (2010). Nepal trade integration strategy, 2010. Kathmandu, Nepal: Author.

Pant, B. (2005). Nepal trade sector: Review, repercussions and recommendations. NRB Economic Review, 17, 89-115.

Poudal, B. (2004). Production and marketing of large cardamom: A case study of Barbote VDC of Ilam district, Nepal (Unpublished master's thesis). Tribhuvan University, Nepal.

Pradhan, P. (2003). Cardamom production in Sikkim: A case study of Rongoli sub-division (Unpublished master's thesis). Tribhuvan University, Nepal.

Sharma, E., Sharma, R., Singh, K. K., \& Sharma, G. (2000). A boon for mountain populations: Large cardamom farming in the Sikkim Himalayas. Mountain Research and Development, 20(2), 108-111.

Sharma, S. (1999). Large cardamom cultivation: A real contribution to village economy (Unpublished master's thesis). Tribhuvan University, Nepal.

Singh, K. A., Rai, R. N., Patrian, \& Bhutia, D. T. (1989). Large cardamom (amomum subulatumroxb.) plantation: An age old agro forestry system in Eastern Himalayas. Agro-forestry System,9, 241-257.

Subedi, B. P. (1982). Large cardamom farming in some villages of Ilam district. The Himalayan Review, 14, 25-37.

Zomer, R. J., \& Menke, J. (1993). Site index and bio-mass productivity estimates for Himalayan aider - large cardamom plantations: A model agro-forestry system of the eastern middle hills of Nepal. Mountain Research and Development, 13(3), 225-255. 